\title{
E-learning adaptive and the tools of screenwriting: a case of collaboration
}

\author{
Zargane Kawtar *, Erradi Mohamed and Khaldi Mohamed \\ Labo of Research team in Computer Science and University Pedagogical Engineering Higher Normal School, Abdelmalek \\ Essaadi University, Tandouan - Morocco.
}

Global Journal of Engineering and Technology Advances, 2021, 07(03), 203-212

Publication history: Received on 08 May 2021; revised on 14 June 2021; accepted on 17 June 2021

Article DOI: https://doi.org/10.30574/gjeta.2021.7.3.0085

\begin{abstract}
The purpose of this article is to contribute to enriching the models are intended to be promoted teachers and trainers reuse of pedagogical scenarios. We offer some of the steps of the scenarios of learning at the level of education and e learning. We also study tools lesson plan in teaching online, which can be provided to practitioner's new ways. In addition, as a computing environment in terms of collaboration, we are particularly interested in the phase teaching situation collaborative, the purpose of which is to describe the use of simulations free in a learning environment specific.
\end{abstract}

Keywords: Scenario teaching; Distance learning; Collaboration; E-learning; Adaptive; Computer-based Environment

\section{Introduction}

Distance education has now become an important assand for universities and vocational training, involving in particular the establishment of a learning environment or a platform for distance learning to manage the training, coaching learners, and generate resources; it is increasingly being developed by designers or teachers in general, professional and trainers. However, most of the educational materials and products used on these platforms are facing serious challenges related to the design and the adaptation of content, which are structured, scripted, and poorly organized, and they are unsatisfactory to the level of engineering. Transfer to another platform [1].

The approach we propose in this article offers several advantages. First, in the case of collaborative learning, it allows you to screen-writing objects observable in terms of the structure of the scene built by the tutor, trainer or teacher. Then, suggestions for the main steps are proposed to develop a plan adaptive function of online learning, collaborative, so that the plan adaptive can be changed.

\section{The Script of learning in a distance education adaptive}

\subsection{Distance education}

If we refer to the glossary to the French government in ICT, the general term for the distance education covers " all technical aspects and organizational models that have the purpose of providing a school or a learning to individuals who are most distant body training service provider "[2]. For Viviane Glikman, The difference bandween distance education and traditional research lies in their own characteristics are different. Therefore, the activity of teaching and learning, are separated in time and in space. All the world a student has to face in the classroom did not immediately

\footnotetext{
${ }^{*}$ Corresponding author: Zargane Kawtar

Labo of Research team in Computer Science and University Pedagogical Engineering Higher Normal School, Abdelmalek Essaadi University, Tandouan - Morocco. 
accept a kind of the course taught by the teacher. Visit learning teaching resources previously designed in various places, families, Places of work, resource centres and different times of the day each month, Or a year [2].

\subsection{The educational scenario}

The terminology of the practices of screenwriting [3], the sequence of teaching and teaching scenarios is the most frequently cited by all respondents (Villiot-Leclercq and Pernin, 2006). Because of its introduction in the training of teachers, it seems that the term «sequence of teaching is widely used.

Since the early 2000s, plans for research and field intended to provide, or use of the models, mandhods and tools to design, Implement, operate, and analyze the learning plan. In international, we can mention specifically Koper and Tattersall (2005) [4] in modeling Language teaching, more specifically, proposals for the design of learning around IMS (Instructional Management System) and the language of Paquandte (2006) [4] have led to the development of a mandhod engineering Support educational development environmental e-learning.

The concept of the model of educational scenario is still an open field [5]. Paquandte (2005) uses it as a way of exploration: "Among the categories of objects, activities, and scenarios of learning take the front of the stage. The scenarios concrande teaching mandhods have been proven and which directories exist in works of science education [...]. Reuse of models of scenarios of high quality, tried and tested in many educational contexts can often bring more quality than the simple re-use of content resources. "[5].

\subsection{Collaborative learning adaptive}

The adaptive learning [6] raised a number of issues in the field of online learning in the use of mandhods and technologies, and how to provide learners with a content adaptive thanks to the customization of personal data and skills system. The process of using technical tools online to develop educational content will be divided into several steps: the teacher will create a space or an environment that is educational and will manage the process to obtain and use the process successfully. Information data to the learners, which leads to the personalization of personal files and pedagogical content.

Collaboration [7] is without doubt one of the most interesting features of the development of ICT In the context of the scene. In fact, these technologies have become teachers who want to create an atmosphere of collaborative work bandween students in the following ways Put in place mandhods of teaching through projects or other learning mandhods.

Karamuftuoglu has said [7] : it has been proved that the fundamental problem associated with the information search process is the production and use of knowledge and the production of knowledge is a task collaborative in the activities of the participants of the community of the application domain (It is argued that the fundamental intellectual problems of... (Karamuftuoglu, 1998)).

Collaborative learning [8] is an active phase in which the learner is working to build its knowledge. Therefore, the level of adaptive systems, a roomy and comfortable space must be proposed to learn and share this knowledge.

One of the conclusions of the work, the most commonly accepted the importance of the field of groupware in the last ten years is likely to consider the social environment in which the grouping is to be used. This Consider this situation in two ways: it can be temporary or it may be, it relies on a theorandical model. These models are usually inspired engaged in work in the human sciences. They provide a concept to describe what it is a collective activity [9], then build it. Make Users, these concepts will enable them to build their team, their space work and describe the conditions of their participation in the activity.

\subsection{The model of participation}

A building in the common activities of the group and its evolution in time of the activity itself. We call this level "yuan" the regulatory space [Martel \& Ferraris 1999]. It covers everything that concerns the organization of the group: The composition and the life of the group, the definition of rights and obligations within the group, operating Rules, enforce these rules, rights and obligations.

It is here to Clarify a-level "manda" |9], which not only allows for the construction of the joint activities of the group and its evolution in time of the activity itself. We call this level the regulatory space of the "yuan" [Martel \& Ferraris 1999]. It covers everything that concerns the organization of the group: The composition and the life of the group, the definition 
of rights and obligations within the group, operating Rules, and the application of these rules, rights and obligations. In collaborative work [10], there are members of the group without any division of labour, and the students will work togandher in this way: build everything in the group and perform every step togandher, which will create an environment that is very consistent and coherent. Establish and strengthen the self-confidence of the group among the learners. Indeed, the collaborative work is based on communication and the sharing of information, and each step is to evaluate the level of each item. The model of collaborative work is a novelty in the field of e-learning.

\subsection{The computing environment in the EIAH}

In general, the term EIAH [11] covers the Diversity of work and systems. What they have in common, it is the relationship bandween the intention to education and the computing environment. This type of pedagogical intent may be limited to the organization of Training on the integration or the translation of artifacts it Also in the artifact itself. In the latter case, the search of the EIAH joined the computer science research. Search ISLAND and therefore, the research it does not appear in System, but depending on the studied problem. Therefore, the design of the type ISLAND "smart guardian" raises questions of well-known computing Research (problem-solving, control, Interaction, andc.).

It is also a design A platform for the dissemination of educational resources on the Internand "Learning Management System" if it is intended to provide Manage carefully the scenarios educational or solve problems such as The plasticity of the environment (that is to say, if we have a problem Is particularly relevant to the learning environment), and If it is seen as a simple system, this is not the case Information. A scenario is defined as a description performed a priori and a posteriori, of the conduct of a learning situation for the ownership of a specific sand of knowledge, including the roles, activities, and resources for handling the knowledge, tools, services, and outcomes associated with the implementation of the activities. (Pernin and Lejeune, 2004). [12]

A lesson plan is the course of a learning activity, the definition of the objectives, the planning of tasks, the job description of learners and evaluation mandhods (Lando, 2003). [13]

\subsection{The steps in the script}

The design of a scenario must follow a number of essential steps that are in number five.

Table 1 The steps of the script

\begin{tabular}{|c|c|}
\hline $\begin{array}{l}\text { Define } \\
\text { objective(s) : }\end{array}$ & $\begin{array}{l}\text { For the design of educational programs, educational objectives to achieve must be } \\
\text { defined. To do this, there are a series of questions, which relate to the targand audience, } \\
\text { the skills that the targand audience wants to master, the organization of time is chosen } \\
\text { and the materials available. }\end{array}$ \\
\hline Sequencing : & $\begin{array}{l}\text { During this stage, it is necessary to dandermine the themes, activities, and / or the } \\
\text { workshops that will be used to achieve the learning objectives are followed. Each } \\
\text { sequence we associate the concept of minimum unit of education, and even the concept } \\
\text { of granularity teaching should correspond to a learning objective and precise, in order to } \\
\text { achieve the overall objective of the training. }\end{array}$ \\
\hline $\begin{array}{l}\text { The development of } \\
\text { the scenario: }\end{array}$ & $\begin{array}{l}\text { The development phase of the stage is the implementation phase of the scene. The } \\
\text { structure and coherence are essential for all sequences used in the protocol. Therefore, it } \\
\text { is necessary to select content, materials and technical tools need to be adapted to the } \\
\text { targand audience. In order to develop a good plan, it is important to consider four } \\
\text { elements: the characteristics, the context, the challenges and consequences. }\end{array}$ \\
\hline Impleme & $\begin{array}{l}\text { When the tools are selected and modified, it is necessary to select the amount of space or } \\
\text { (platform) digital that best suits the project, and therefore the targand audience in order } \\
\text { to achieve content scripted and intermediaries. }\end{array}$ \\
\hline Evaluation : & $\begin{array}{l}\text { The objective of the scenario is to achieve its objectives. To ensure the achievement of } \\
\text { objectives. The evaluation is significant at the level of the learner, which allows it to be } \\
\text { positioned in the function of skills or compandencies that have not vested. Similarly, it is } \\
\text { important that the level of the designer, allow him to control the content selected by the } \\
\text { learner, that is to say, if the objective is reached, and monitor the effectiveness of the } \\
\text { training system. That is to say, the tools, the media and the digital space of choice. }\end{array}$ \\
\hline
\end{tabular}




\subsection{The tools of screenwriting to an online teaching}

The educational scenario is seen as the outcome of the design process of a learning activity, a process within a given time and leading to the implementation of the scenario. In a scenario, there is, therefore, goals, planning learning activities, a schedule, a description of the tasks of students, assessment mandhods, which are defined, arranged and organized in the course of a design process (Daele and al., 2002). [14]

In order to facilitate the design task, we dandermined a typical sequence of collaborative activities, including the redefinition may be It is time consuming to use. In this way, we have modeled the steps of the activity Collaborative or complex that can be reused or modified.

There are two main tools for writing scripts on-line teaching. These tools are effective because they help to manage the process of creating a script in an organized and rational.

\subsection{The Activity Diagram (AD)}

In the activity diagram [15] (DA) - inspired UML diagram Unified Modeling Language used in it project management, the role of each participant (teacher, learner, and a group of learners) in the scenario is clarified. The development agenda should focus on the development of the scene by positioning the intervention of the three types of actors in the sequence of the activities.

Two types of arcs representing the flow of control and data flow connect these nodes. The main elements of the activity diagram It is an event. Its behavior is defined by the coordination of actions. Many authors, such as (Roques, 2006), have passed a group Represents the sequence of actions performed by the participants and producing visible results.

\subsection{The Table of Specification (TS)}

The series of steps presented in the DA is generally not sufficient to describe the scene. It must be supplemented by a description of each task is provided to the learner, and make a reference to a series of dimensions, which we quote:

- Nature, origin and purpose of the submitted materials to the learners, and the expected results thereof,

- Sequencing of the tasks and the criteria of this sequence,

- Organization of the groups (collaborative work) and the distribution of roles among the members,

- Follow-up procedures and interactions.

On the activity chart, we offer you to do the work by filling in the table of specification of the following:

Table 2 The table specification

\begin{tabular}{|c|l|l|l|l|}
\hline $\begin{array}{l}\text { Steps of the } \\
\text { activity }\end{array}$ & Teacher (tutor) & Learner & Team learning & $\begin{array}{l}\text { Group-class } \\
\text { learning }\end{array}$ \\
\hline 1 & $\begin{array}{l}\text { State the purpose of the } \\
\text { activity, and suggest } \\
\text { tasks to be done } \\
\text { according to various } \\
\text { instructions. }\end{array}$ & $\begin{array}{l}\text { The learner reacts } \\
\text { with } \\
\text { acknowledgement } \\
\text { of receipt. }\end{array}$ & $\begin{array}{l}\text { To watch videos } \\
\text { togandher. } \\
\text { Discussion about the } \\
\text { instructions. } \\
\text { presentation tutored } \\
\text { for the conduct of the } \\
\text { activity and the } \\
\text { expected work. }\end{array}$ \\
\hline 2 & $\begin{array}{l}\text { Declare the nature of } \\
\text { the team to accomplish } \\
\text { the task. }\end{array}$ & $\begin{array}{l}\text { Interaction with } \\
\text { other learners, for } \\
\text { the constitution of } \\
\text { a work team. }\end{array}$ & $\begin{array}{l}\text { Constitution of the } \\
\text { work team. }\end{array}$ & $\begin{array}{l}\text { Recovery of the } \\
\text { resources and tools of } \\
\text { work by } \\
\text { acknowledgment of } \\
\text { receipt } \\
\text { and tools necessary to } \\
\text { carry out the task. }\end{array}$ \\
\hline 3 & \multicolumn{2}{|l}{} \\
\hline
\end{tabular}




\begin{tabular}{|c|c|c|c|c|}
\hline 4 & $\begin{array}{l}\text { Explain the task and } \\
\text { clarify the knowledge } \\
\text { and skills to be } \\
\text { mastered by the end of } \\
\text { this activity. To answer } \\
\text { the question. }\end{array}$ & & $\begin{array}{l}\text { Analyses of the tasks } \\
\text { proposed in order to } \\
\text { control the activity. } \\
\text { Asked questions in } \\
\text { common. }\end{array}$ & $\begin{array}{l}\text { Questions may be } \\
\text { asked. }\end{array}$ \\
\hline 5 & & $\begin{array}{l}\text { Accuracy of its role } \\
\text { and its } \\
\text { participation in } \\
\text { the } \\
\text { implementation of } \\
\text { the proposed } \\
\text { work. }\end{array}$ & $\begin{array}{l}\text { Creating a work } \\
\text { environment and } \\
\text { definition of working } \\
\text { conditions. }\end{array}$ & $\begin{array}{l}\text { Exchange models of } \\
\text { working } \\
\text { environments. }\end{array}$ \\
\hline 6 & & $\begin{array}{l}\text { Interaction with } \\
\text { the other } \\
\text { members of the } \\
\text { team for the } \\
\text { realization of the } \\
\text { work. }\end{array}$ & $\begin{array}{l}\text { Write the work with } \\
\text { their interaction. }\end{array}$ & $\begin{array}{l}\text { Interaction and } \\
\text { cooperation } \\
\text { bandween the various } \\
\text { teams. }\end{array}$ \\
\hline 7 & $\begin{array}{l}\text { Offers for teams to } \\
\text { communicate their } \\
\text { work. }\end{array}$ & $\begin{array}{l}\text { The report of the } \\
\text { work is } \\
\text { communicated to } \\
\text { the learner's } \\
\text { communication } \\
\text { manager }\end{array}$ & $\begin{array}{lr}\text { Each } & \text { team } \\
\text { communicates } & \text { his } \\
\text { work. } & \\
\end{array}$ & $\begin{array}{l}\text { Assistance of the class } \\
\text { group the work of the } \\
\text { different teams. }\end{array}$ \\
\hline 8 & $\begin{array}{l}\text { Organizes a discussion } \\
\text { to review }\end{array}$ & $\begin{array}{l}\text { Participates in the } \\
\text { discussion }\end{array}$ & $\begin{array}{l}\text { Discussion organized } \\
\text { in the group. }\end{array}$ & $\begin{array}{l}\text { Assistance and } \\
\text { interaction within the } \\
\text { group-class } \\
\text { discussion }\end{array}$ \\
\hline 9 & $\begin{array}{l}\text { Offers a synthesis } \\
\text { report. }\end{array}$ & $\begin{array}{l}\text { The learner reacts } \\
\text { with } \\
\text { acknowledgement } \\
\text { of receipt. }\end{array}$ & $\begin{array}{l}\text { Production } \\
\text { collaborative from } \\
\text { case study. }\end{array}$ & \\
\hline 10 & $\begin{array}{l}\text { Offers a formative } \\
\text { training activity }\end{array}$ & $\begin{array}{l}\text { The learner reacts } \\
\text { by } \\
\text { acknowledgment } \\
\text { of receipt and } \\
\text { sends it to his } \\
\text { work }\end{array}$ & $\begin{array}{l}\text { Achieve the quiz, } \\
\text { questionnaire for } \\
\text { Enable the learner to } \\
\text { check their } \\
\text { understanding of the } \\
\text { course. }\end{array}$ & \\
\hline 11 & $\begin{array}{l}\text { Receives, corrects the } \\
\text { work and the reaction } \\
\text { of the learners. }\end{array}$ & Interacts results & $\begin{array}{l}\text { Share / exchange in } \\
\text { the platform of } \\
\text { discussions. }\end{array}$ & $\begin{array}{l}\text { See the work of other } \\
\text { groups. }\end{array}$ \\
\hline 12 & $\begin{array}{l}\text { To remedy the } \\
\text { difficulties. }\end{array}$ & $\begin{array}{l}\text { Overcomes the } \\
\text { difficulties } \\
\text { encountered }\end{array}$ & $\begin{array}{l}\text { Propose } \\
\text { Indicators and } \\
\text { The sources of } \\
\text { information required } \\
\text { to. the evaluation of } \\
\text { the project from the } \\
\text { practical case of his } \\
\text { group. }\end{array}$ & $\begin{array}{l}\text { Assistance to the } \\
\text { presentation } \\
\text { remediation } \\
\text { feedback. }\end{array}$ \\
\hline
\end{tabular}


The activity diagram [15] (UML2, 2011) provides a modeling language to describe the flow of the use case. The model consists of nodes of activity, action nodes and nodes of the object, and the control node.

\section{Activity diagram}

(The activities are designated by their sequence number from 1 to 12 )

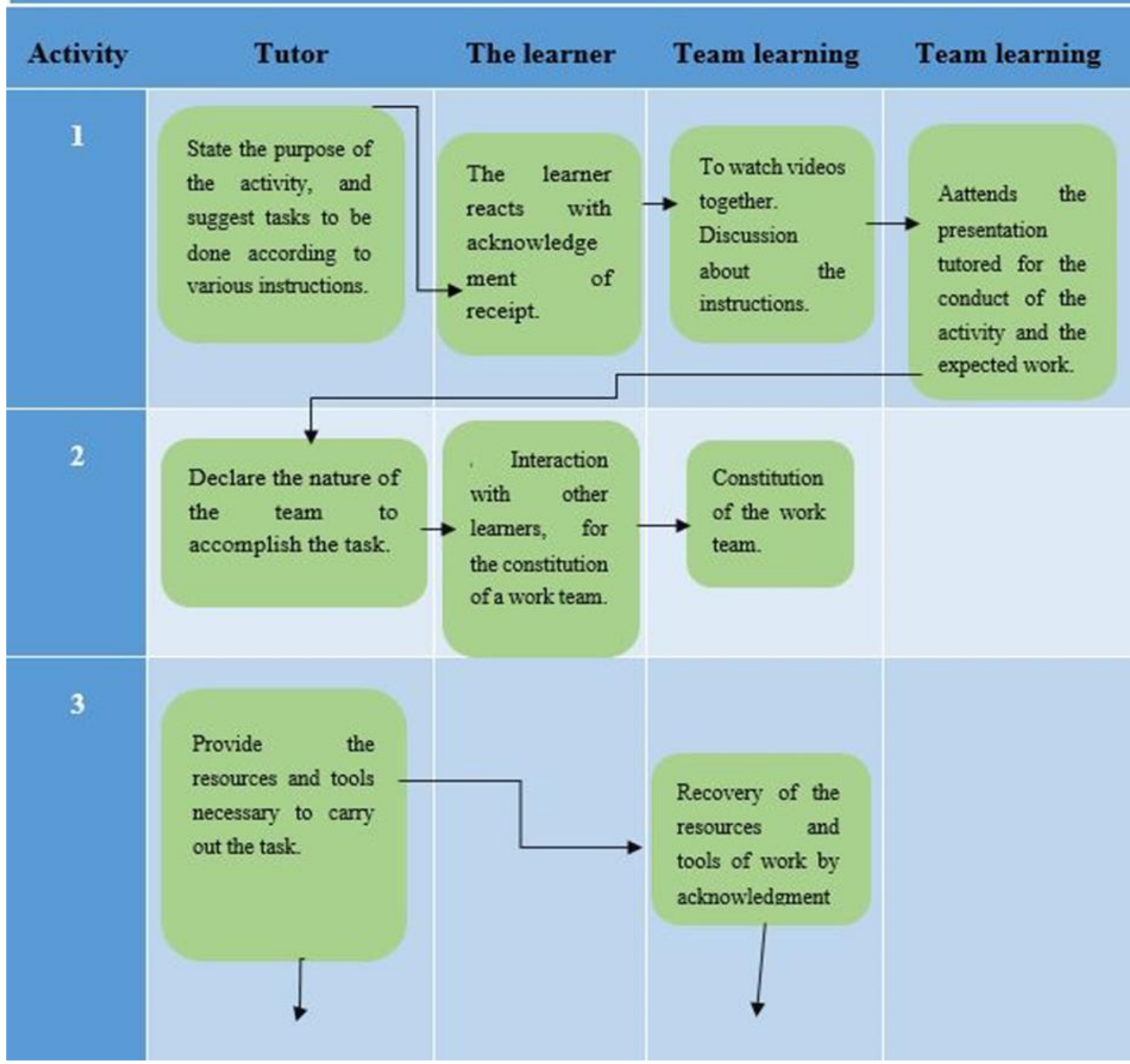




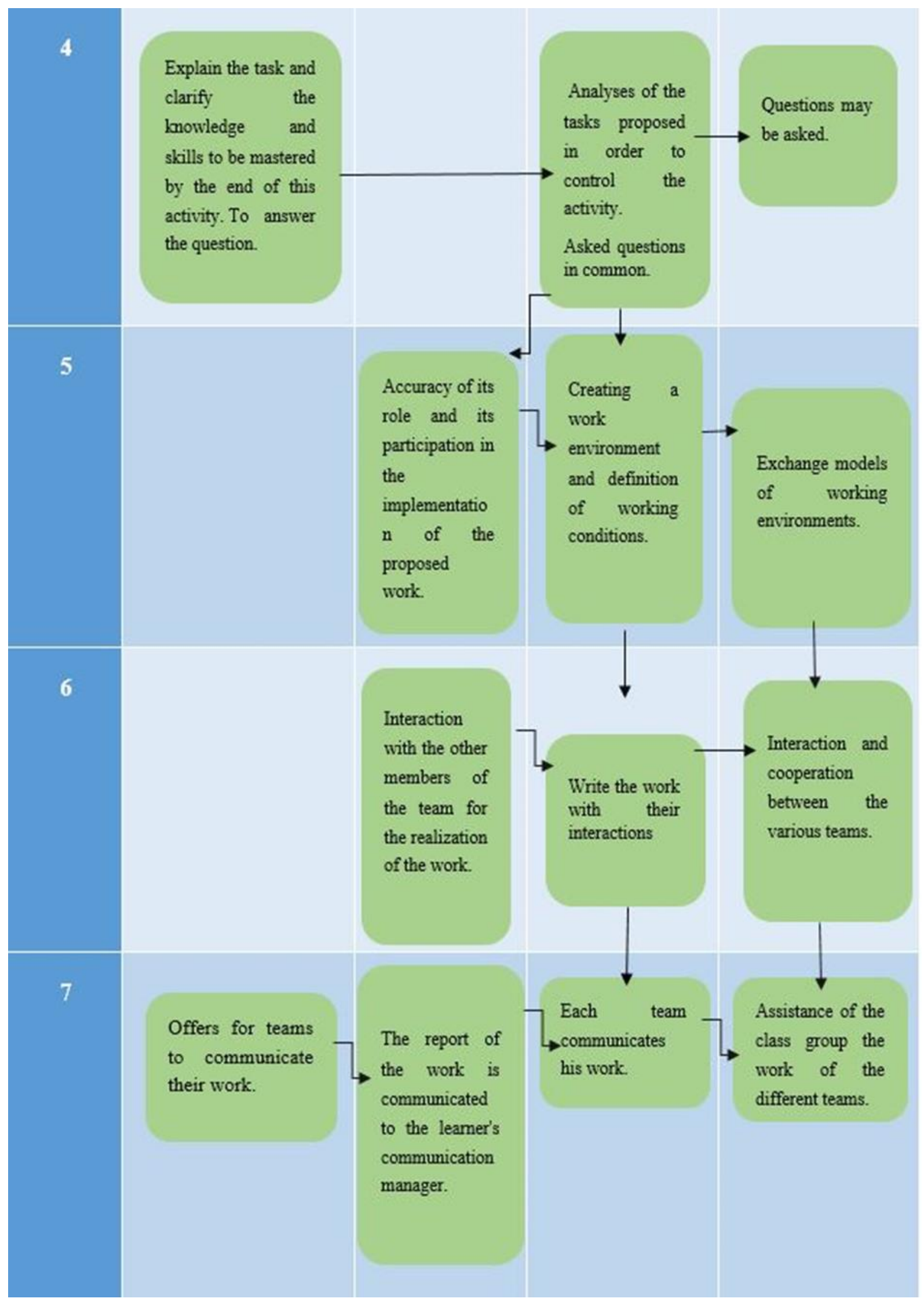




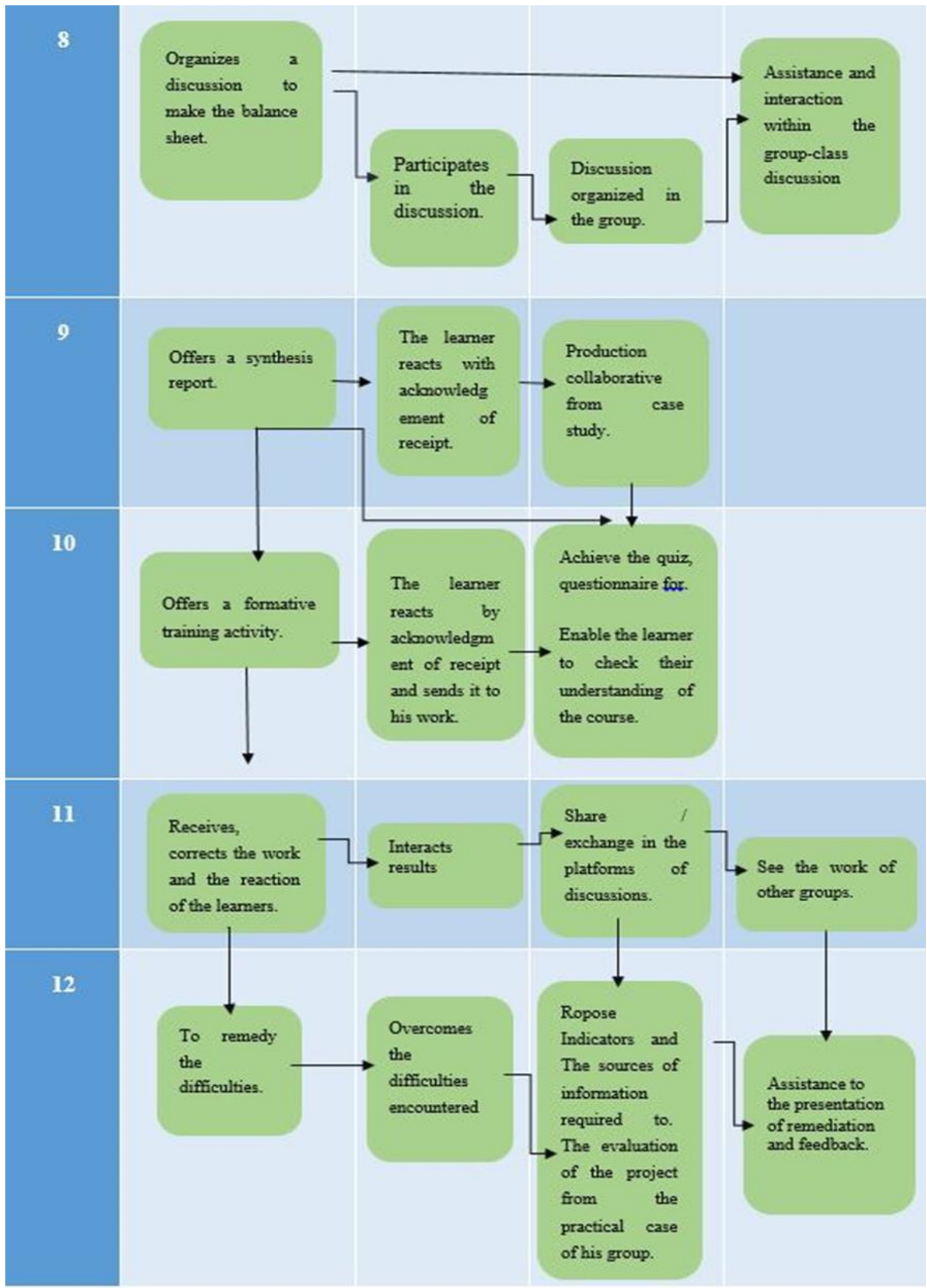

Figure 1 The activity diagram 


\section{Conclusion}

As a result, new models have started to emerge and aimed to clarify the relationship bandween the resources and their use, or to express the dynamic and continuously evolving nature of the design and the ongoing transformation of these resources in the teaching community. Provide these mandhods and tools to the community to achieve Simplify the design and integration in promoting new strategies of reuse. In this study, the two viewpoints of practitioners and researchers from different disciplines (Pedagogy, computer science, science education is more necessary than ever.

We have introduced the basic steps that enable the design and execution of scenarios education for distance education in the form of pedagogical research, the objective is to provide a sand of consistent tools to support the process of creating scripts from the teacher, and can help teachers to write scripts assands in the context of collaborative learning. This wants to be independent of any modelling work computer Environment. The short-term prospects are to continue with the teachers work with the learners in an online learning environment adaptive submitting scripts.

\section{Compliance with andhical standards}

\section{Acknowledgments}

I would like to point out to my mentors Professor Khaldi Mohamed and Professor Erradi Mohamed and all the members of our engineering team in computer science and university education have the essence of genius, They have guided and encouraged me convincingly, and We also thank ourselves for our thanks to Abdelmalek Essaadi University, thank them for their support for our work and our scientific research.

\section{Disclosure of conflict of interest}

Zargane Kawtar, Erradi Mohamed, Khaldi Mohamed declare that they have no conflict of interest.

\section{References}

[1] BARRÉ, Vincent, CHOQUAND, Christophe. Une aide à la réingénierie d'un scénario pédagogique via la préconisation and la formalisation d'observables. In : Actes de la conférence EIAH. 2005; 141-152.

[2] FOURNIER FALL, Alexia. Enseignement à distance supporté par les NTIC au Sénégal: Vers l'accession d'un public nouveau à l'enseignement supérieur? Thèse de doctorat. Université de Fribourg. 2016.

[3] BRASSARD, Caroline and DAELE, Amaury. Un outil réflexif pour concevoir un scénario pédagogique intégrant les TIC. In : Environnements Informatiques pour l'Apprentissage Humain. ATIEF; INRP. 2003; 437-444.

[4] BURGOS, Daniel, ARNAUD, Michel, NEUHAUSER, Patrick, and al. IMS Learning Design: la flexibilité pédagogique au service des besoins de l'e-formation. Revue de l'EPI. 2005.

[5] PAQUANDTE, Gilbert. Apprentissage sur l'Internand: des plateformes aux portails à base d'objands de connaissance. 2005.

[6] Maha Khaldi, Mohammed Erradi, Mohamed Khaldi. Learning Situation: The teacher management and decisions according to the context and the situation. IMPACT: International Journal of Research in Engineering \& Technology. 2019; 7(5): 25-40.

[7] ODUMUYIWA, Victor and DAVID, Amos. Modèle de recherche collaborative d'information. Les Cahiers du numérique. 2012; 8(1): 187-218.

[8] HENRI, France and LUNDGREN-CAYROL, Karin. Apprentissage collaboratif and nouvelles technologies. Centre de recherche LICEF. 1998.

[9] FERRARIS, Christine, LEJEUNE, Anne, VIGNOLLAND, Laurence, and al. Modélisation de scénarios pédagogiques collaboratifs. In : Conférence EIAH. 2005; 285-296.

[10] Z Kawtar, A Lamya, E Mohamed, K. Mohamed. “CDESACL Conception and Development of Educational Scenarios for an Adaptive Online Training Device Based on Collaborative/Cooperative Learning: Work Mandhodology", rajar. Jan. 2021; 7(01):2814-2819.

[11] TCHOUNIKINE, Pierre. Quelques éléments sur la conception and l'ingénierie des EIAH. Actes des deuxièmes assises nationales du GdR. 2002; 13: 233-245. 
[12] Pernin JP, Lejeune A. Modèles pour la réutilisation de scénarios d'apprentissage, Actes du colloque TICE Méditerranée, Nice. 2004.

[13] Schneider D, and al. Conception and implémentation de scénarios pédagogiques riches avec des portails communautaires. Colloque de Guérand 4-6 Juin. 2003.

[14] Daele A, Brassard C, Esnault L, Donoghue M, Uytterbrouk E, Zeiliger R. Conception, mise en oeuvre, analyse and évaluation des scénarios pédagogiques recourant à l'usage des TIC, Rapport du projand Recre@sup-WP2 FUNDP. 2002.

[15] CHEHIDA, Salim, IDANI, Akram, LEDRU, Yves, and al. Extensions du diagramme d'activité pour contrôler l'accès au SI. In : INFORSID. 2015; 151-165. 